\title{
609 無段変速機を用いた効率の良い \\ パワースプリット差動遊星機構の設計法 \\ Design method of high efficiency power split type differential planetary mechanism including CVT
}

\author{
正員 矢田恒二（矢田技術士事務所） \\ Tsuneji YADA, YADA Engineering Consulting Office, 2-7-8 Komaba, Toride, Ibaraki
}

\begin{abstract}
This paper investigates the power split type differential planetary mechanism (SDM) that includes CVT and is possible to operate in high efficiency region. There are two regions indicating high efficiency in the coordinate, horizontal axis of which is $\omega_{1} / \omega_{3}$ and vertical axis $\omega_{2} / \omega_{3}$, where $\omega_{3}$ is angular velocity of input shaft of planetary system, $\omega_{1}$ and $\omega_{2}$ are velocities of other two shafts of it. The paper shows planetary mechanism possible to set operating point in the high efficiency region. Using CVT as an apparatus to realize operation in high efficiency region, SDM having high efficiency can be obtained.
\end{abstract}

Keywords: CVT, planetary gear, power split, efficiency, traction drive, design

1.はじめに

著者は既に遊星歯車機構の特性線図を提唱し、これを用 いることによって差動遊星機構を見通し良く設計できる

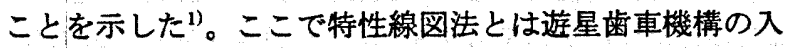
力軸角速度を $\omega_{3}$ 、他の 2 軸の角速度を $\omega_{1} 、 \omega_{2}$ としたとき、 $\omega_{1} / \omega_{3}$ を横軸、 $\omega_{2} / \omega_{3}$ を縦軸とする座標内に於いて、 遊星歯車機構を固有の $J$ 直線で表現する方法である。本文 ではこれを用いることによって、無段変速機 (CVT) を組み 込んだパワースプリット型差動遊星機構(SDM)において、 高効率の機構を設計する方法について述べる。

\section{2 . 効率の高い領域}

CVTと遊星歯車機構とを組み合わせることによって様々 な変態形態を持つ変速機構を構成することができる。図1 はそのシステムを概念的に表したもので、几注遊星歯車機 構、Rは無段変速機を示している。ここでは遊星苗車機構 は動力の分配機構的な役割をするために、その組み合わせ 方によって動力の流れもいろいろな形が発生する。大まか に分ければ入力動力が内部でわかれて再度出力側で合流 する分流型(これをパワースプリット型と呼ぶ) と、入力動 力とは別の動力が内部で発生して循環動力流を発生させ る動力循環型とに分けることができる。
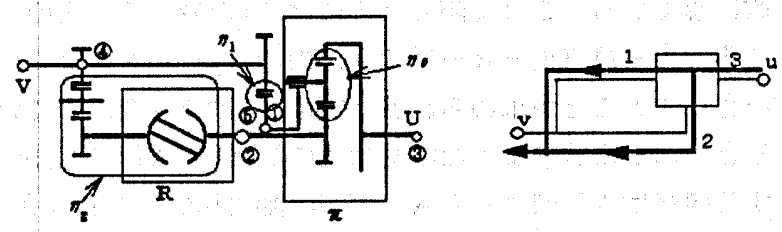

Fig 1 Example of SDM and power flow

パワースプリット型では入力動力がわかれて流れるが 大きな動力が流れる部分に効率の患い要素を持ってくる
ことは得策ではない。通常歯車列よりもCVTの方が効率は 悪いので、CVTには小さい動力が流れるように設計する必 要がある。

図2は遊星歯車機構の基淮効率(キャリアを固定したと きの効率)を $99 \%$, VVTの効率を $95 \%$ としたときの速度と効率 分布の関倸を示したものである。ここで横軸は $\omega_{1} / \omega_{3}$ 、 檤軸は $\omega_{2} / \omega_{3}$ を表した特性座標を逆数座標を用いて表 したもので、ここでの座標軸のスケールは絶対值が1より 小さい範囲は通常のスケール、1より大きいときは逆数の スケールで表している。

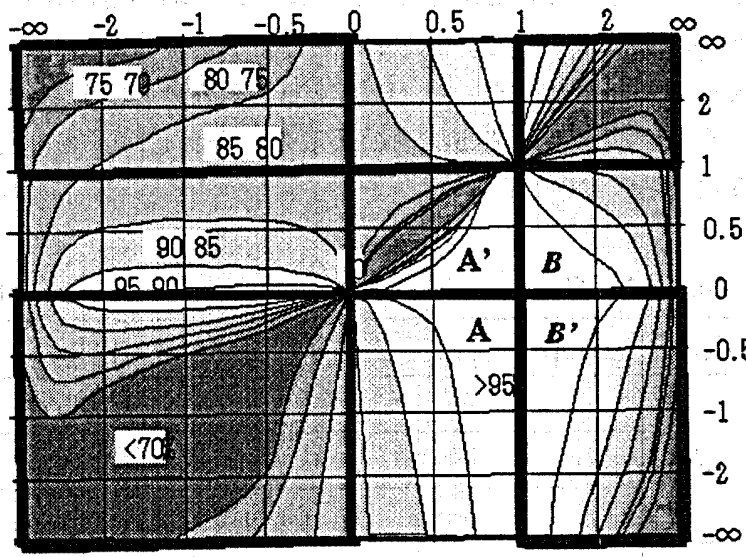

Fig 2 Efficiency contour of SDM

この図 2 に於いて動力循環の発生する部分は太線の枠 内の部分でそれ以外は動力分流状態て動力が伝えられる 領域を示している。また図の白拔きの部分は効率 $95 \%$ 以上 の領域を示しているので、効率の良い差動遊星機構を設計 するときにはこの領域に動作点のあることが必要となる。 したがってパワースプリット型で効率のよい機構を設計

日本機械学会関東支部第 9 期総会講演会講演論文集 ['03-3-14,15,横浜市] 
するためには図 2 の A、Bで示した領域に動作点を見つけ る問題に帰着する。なお動力循環型でも $A^{\prime} 、 B^{\prime}$ の領域 では効率の良い部分のあることがわかる。

3. 遊星歯車機構要素と端子の組合わせ

特性線図に於いて座標点 $(1,1)$ を通る $J$ 直線は遊星歯車 機構固有の構造を示し、1個の遊星歯車機構には 6 個の $J$ 直線のあることがわかっている。また差動遊星機構を構成 するCVTを含む(2)-R一歯車列－(1)の回路の速度比 $r$ は 原点を通る直線で表され、速度比が変化する場合にこの直 線の勾配が速度比の最大值と最小值にある直線群で示さ れる。したがってCVTの速度比が変化するときのこの差 動遊星機構の動作点はJ直線上における $r$ の直線群の交 点の間にある (図 3 )。

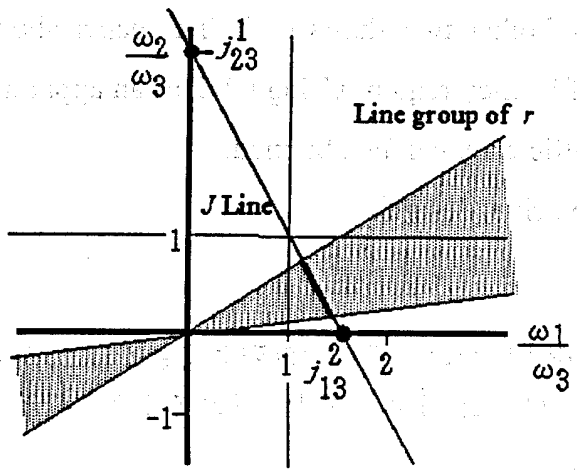

Fig 3 Operation zone of SDM

1 個の遊星歯車機構は 6 個の $J$ 直線を持つが、一つの $J$ 直線に注目したとき、それに対応する遊星歯車機構は遊星 歯車機構の 3 個の要素、すなわちキャリアと二個の太陽歯 車(ここでは内歯歯車も太陽歯車と見なす)とが、外部に接 続することのできる端子と、どのようにの組み合わせられ るかによって決まる。ここで対象とする遊星歯車機構を 2 $\mathrm{K}$-H型としたとき、A，B領域の効率の良い部分を通る $J$ 直線を持つ遊星歯車機構の端子の組合わせは、表1のよ うになる。

Table 1 Combination between terminal and element

\begin{tabular}{|c|c|c|c|c|c|}
\hline Zone & group & (1) & (2) & (3) & $j_{s i}^{H}$ \\
\hline \multirow{3}{*}{ A } & a & $\mathrm{H}$ & $\mathbf{s}$ & $\mathbf{i}$ & $-1>j_{s i}^{H}$ \\
\hline & b & $\mathrm{i}$ & $\mathbf{s}$ & $\mathrm{H}$ & $j_{s i}^{H}>2$ \\
\hline & c & i & $\mathrm{H}$ & $\mathbf{s}$ & $2>j_{s i}^{H}>1$ \\
\hline \multirow[t]{2}{*}{$B$} & $\mathrm{~d}$ & $\mathrm{i}$ & $\mathbf{s}$ & $\mathrm{H}$ & $-1>j_{s i}^{H}$ \\
\hline & e & s & $\mathrm{H}$ & i & $j_{s i}^{H}>1$ \\
\hline
\end{tabular}

ここで(1)、(2)、(3)は端子を示し、Hはキャリア、sは小 径の太陽歯車、i a グループでは端子(1)とキャリアH、(2)と小径太陽歯車、 (3)と大径太陽歯車が組み合さっていることを示している。 また $j_{\mathrm{si}}^{\mathrm{H}}$ はキャリアを固定したときの伝達比(=小径太陽 歯車の角速度／大径太陽歯車の角速度)を示している。こ
の值は遊星歯車機構の構造とも関連していて、 $j^{{ }^{H}}{ }_{s i}<-1$ の場合は太陽歯車と内歯歯車からなる通常の遊星歯車機

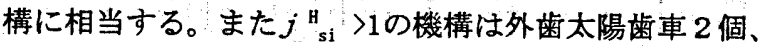
あるいは内歯歯車 2 個からなる遊星歯車機構であり、ラビ 二オウ型遊星歯車機構もこの条件に当てはまる。

さらに表 1 のZone A、Bは先に示した領域を示してい る。ここでA領域に該当する機構で $j^{\mathrm{H}}{ }_{\mathrm{si}}>2$ と、 $2>j^{\mathrm{H}}{ }_{\mathrm{si}}>1$ の2種類の機構があるのは、同じ機構構成を持っている遊 星歯車機構のなかで小径太陽歯車と大径太陽歯車の大き さの差の関係によって決まってくるためである。表 1 に示 す端子と要素の組合わせの具体的な構成の例を図 4 に示 す。

\section{4. 効率の高い差動遊星歯車機構}

差動遊星機構としては図 19機構の端子(1)、(2)に、表 1 に示す遊星歯車機構の端子を接続することで、高効率のパ ワースプリット型遊星歯車機構を構成することができる。 ここで無段変速機 (CVT)の速度比はCVTの構造によって定 まるが、図3で示されている座標上では原点を通る直線群 で表される。しかしその勾配は $\omega_{2} / \omega_{1}$ で表されるので、 図の機構では(1)-歯車列-R－(2)の回路をたどったとき に変換される角速度 $\omega_{2}$ と $\omega_{1}$ の比として表される。ここで $\omega$ 符合を持つ值であるので回転方向が相互に異るとき はこの比はマイナス符合を持つので、原点を通る直楾の勾 配は右下がりになる。

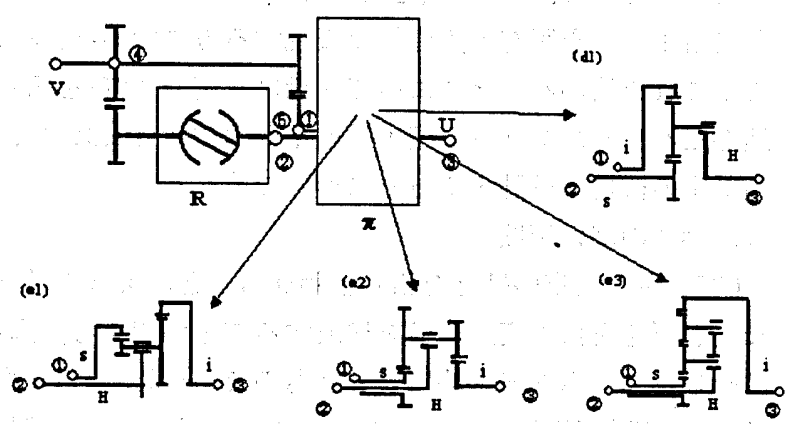

Fig 4 High efficiency SDM in zone B

ところでCVTのなかには速度比が1を境に減速領域と増 速領域を持つものがある。この場合 $\omega_{2} / \omega_{1}$ が1より大き くなると、B領域に動作点を取ろうとしていても、動作点 座標が (1、1)より大きくなり、動作点はB領域から外れ動 力循環部分に動作点が移る。そのためこの所では効率は急 激に悪くなる。これを防ぐためにはCVTの最大速度比のと ころで(1)一歯車列-R－(2)の回路内の $\omega_{2} / \omega_{1}$ を 1 より 小さくすることが求められる。A 領域に動作点を求めてい るときはB領域のような制約は比較的緩い。A領域で動作 する機構はA領域よりも $\mathrm{A}^{\prime}$ 領域の動力循環型で動作さ せるようにした方が高効率を得やすいのが特徴である。

参考文献

1）矢田恒二 機械の研究 vol, 49, No10-vol, 52, Nol1 